\title{
Purification, Electron Microscopy, and Serology of Dioscorea Latent Virus ${ }^{1}$
}

\author{
H. E. Waterworth, R. H. Lawson, and R. P. Kahn²
}

\section{INTRODUCTION}

Virus-like diseases of yam, Dioscorea spp., have been reported to reduce yields significantly (1). Five distinct virus-like disease syndromes were described by Ruppel et al. (5) in Dioscorea plants in Mayagüez, Puerto Rico in 1963. A "nondescript mosaic" and green-banding were the two predominant symptoms. The planting consisted of several species and hybrids. It was not known if the variations in symptoms were induced by more than one virus or by a variation in response among the several species. A survey in 1964 revealed that 95 percent of the planting was infected and that the green-banding symptom predominated.

Ruppel et al. (5) reported that plants of $D$. composita and $D$. floribunda developed green-banding symptoms when rubbed with inoculum from plants affected with mosaic or green-banding. The agent that incited the green-banding symptom was also transmitted by the cotton aphid, Aphis gossypii Glover.

Lawson et al. (4) observed pinwheel inclusions in parenchyma cells, in addition to masses of another virus-like particle $395-445 \mathrm{~nm}$ in length. The pinwheel inclusions were associated with an aphid-transmissible virus that induced green-banding (DGBV) in $D$. floribunda seedlings. The present report describes the purification, serology, and physical properties of the $395-445 \mathrm{~nm}$ virus that was latent in Dioscorea. This virus is referred to in this report as dioscorea latent virus (DLV).

\section{MATERIALS AND METHODS}

Roots of Dioscorea floribunda Mart. and Gal. and D. composita Hemsl. from Mayagüez, Puerto Rico were grown in quarantine at the Plant Introduction Station at Glenn Dale, Maryland. Leaves of both species showed mosaic and green-banding symptoms described by Ruppel et al. (5).

Antisera to some viruses in the potato virus X (PVX) and Y (PVY) groups were kindly supplied as follows: White clover mosaic (WCM) from

1 Manuscript submitted to Editorial Board November 20, 1973.

2 Research Plant Pathologists, Plant Introduction Station, Agricultural Research Service, U.S. Department of Agriculture, Glenn Dale, Maryland; and Research Plant Pathologist, Agriculture Research Center-West, ARS, USDA, Beltsville, Maryland. Appreciation is extended to Dr. Floyd F. Smith for aphid-transmission work, and to Suzanne Hearon and W. R. Povish for technical assistance. 
R. Goth; clover yellow mosaic (CYM) from D. Purcifull and R. Ford; PVX and PVY from D. H. M. Van Slogteren; and Colombian datura virus (CDV) from R. Bartels. In addition, antisera to tobacco etch (TEV), henbane mosaic (HMV), Cymbidium mosaic (CymMV) and to rod-shaped viruses in other groups, were either produced in our laboratories or obtained from the American Type Culture Collection.

Equipment and techniques used to determine physical properties and an experimental host range of DLV have been described (7).

\section{PURIFICATION}

Fresh $D$. floribunda leaf tissue from naturally infected plants with greenbanding symptoms was blended 2 to $3 \mathrm{~min}$ in three volumes (w/v) of cold $0.025 M$ phosphate buffer ( $\mathrm{pH}$ 7.2) containing $0.02 M$ 2-mercaptoethanol. The slurry was pressed through cheesecloth and the juice centrifuged at $3,500 \mathrm{~g}$ for $15 \mathrm{~min}$. The green supernatant was then clarified by using either activated charcoal (Merck 18351) ${ }^{3}$ and a 1 percent suspension of crude bentonite or with magnesium-treated bentonite alone (3). Use of these materials and low-speed centrifugation resulted in clear yellow juice, which in turn yielded glassy pellets with little obvious contaminating plant material after high-speed centrifugation.

Charcoal was mixed with the first low-speed supernatant at $3 \mathrm{~g}$ per 100 $\mathrm{ml}$ of juice, allowed to incubate 15 to $20 \mathrm{~min}$ at $4^{\circ} \mathrm{C}$, and finally centrifuged at $3,500 \mathrm{~g}$. Then 3 to $5 \mathrm{ml}$ of 1 percent bentonite per $100 \mathrm{ml}$ of juice were added. Flocculation occurred after 10 to 15 minutes, and the sample was centrifuged at $3,500 \mathrm{~g}$.

In other experiments, only magnesium-treated bentonite was used to clarify the sap after the first low-speed centrifugation. The bentonite was mixed with the supernatant at the rate of $4 \mathrm{ml}$ per $100 \mathrm{ml}$, incubated for 10 to $15 \mathrm{~min}$, and centrifuged at $3,500 \mathrm{~g}$. A small additional amount of bentonite was added and the sample re-centrifuged if not free of green material after the initial centrifugation.

High-speed pellets were covered with 0.5 to $1.0 \mathrm{ml}$ of $0.025 \mathrm{M}$ phosphate or borate buffer and stored overnight at $4^{\circ} \mathrm{C}$. The pellets were resuspended, combined, and centrifuged again at $3,500 \mathrm{~g}$ to remove traces of plant material. Resuspended virus was layered onto 10 to 40 percent sucrose gradients in $0.025 M$ phosphate buffer. The gradients were centrifuged at $95,000 \mathrm{~g}$ in a swinging-bucket rotor $2 \mathrm{~h}$ and fractionated through an ISCO system (Instrumentation Specialties Company, Lincoln, Nebraska). Reconcentrated virus from gradient fractions associated with the ultraviolet

a Mention of specific equipment, trade products, or companies does not constitute their endorsement by the U.S. Department of Agriculture over similar products not mentioned. 
light-absorbing region was rubbed on leaves of $D$. composita. These plants were held for 6 months for the appearance of disease symptoms.

\section{ELECTRON MICROSCOPY}

Purified virus from density gradients was dialyzed in $0.025 M$ phosphate buffer overnight. Particles were stained with 2 percent phosphotungstic acid adjusted to $\mathrm{pH} 7.0$ with $\mathrm{KOH}$. Particles were measured with $312-\mathrm{nm}$ and 500-nm polystyrene as size standards. Dip preparations were made from naturally infected Dioscorea plants, from seedling Dioscorea plants inoculated with gradient fractions, and from healthy seedlings (4).

\section{IMMUNIZATION AND SEROLOGY}

A rabbit was injected intramuscularly once a week for 4 weeks. Two to $3 \mathrm{mg}$ of the purified virus in $1 \mathrm{ml}$ of $0.025 \mathrm{M}$ buffer was emulsified with an equal volume of Freund's incomplete adjuvant for each injection. The microprecipitin technique (6) was used to determine antiserum titer and serological relationships to other viruses. Purified virus and its antiserum were tested against the above viruses and their respective antisera.

\section{RESULTS}

\section{PURIFICATION}

Yields of purified virus ranged from 8 to $13 \mathrm{mg} / 100 \mathrm{~g}$ of fresh leaf tissue among nine experiments. Virus appeared in gradients as a single opalescent band $3 \mathrm{~cm}$ below the meniscus. Gradients contained one infectious zone which coincided, when fractionated and monitored with ultraviolet light at $254 \mathrm{~nm}$, with the single peak. However, none of the Dioscorea plants, inoculated with infectious gradient fractions, developed symptoms.

Numerous attempts were made to transmit DLV from infected Dioscorea to young Dioscorea seedlings by aphids over a 3-year period. However, the virus was not transmitted by the green peach aphid, Myzus persicae (Sulzer) in any of these tests.

\section{BLECTRON MICROSCOPY}

Seventy-four percent of the particles in purified preparations measured $395-455 \mathrm{~nm}$ (fig. 1). Virus particles ranged in length from 325 to $475 \mathrm{~nm}$ but most particles were $400-450 \mathrm{~nm}$ (fig. 2). Particles of similar size were observed in dip preparations from symptomless plants inoculated with the gradient-separated sample (fig. 1). Particles 700 to $800 \mathrm{~nm}$ long of the DGBV were never observed in purified virus samples. Virus particles were not found in seedlings that had not been inoculated. 


\section{SEROLOGY}

The titer of homologous antibody rose to $1: 16,000$ in successive bleedings of the rabbit. Reactions to healthy plant proteins with antiserum diluted more than 1:2 were not observed.

A serological relationship between DLV and four viruses of the potato virus $\mathrm{X}$ group or with four viruses of the potato virus $\mathrm{Y}$ group could not be demonstrated. Each of the viruses WCMV, CYMV, CyMV, and PVX of the potato virus $\mathrm{X}$ group, and PVY, TEV, HMV, CDV, of the potato virus $\mathrm{Y}$ group, reacted positively with its respective antiserum, but none reacted with the DLV antiserum. Likewise, DLV did not react with the antisera to any of these eight viruses.

In one-way tests, purified DLV did not react with antisera to: bean yellow or common mosaic, chicory yellow blotch, chrysanthemum B or vein mottle, freesia mosaic, carnation latent, red clover vein mosaic, hyacinth mosaic, lettuce mosaic, lilac mottle, lily latent, narcissus yellow stripe, pea streak, plum pox, peanut mottle, tulip breaking, or turnip mosaic viruses.

Antiserum to DLV, diluted 1:64 to $1: 4,000$, reliably detected DLV directly from Dioscorea sap. Virus was extracted by blending leaves with cold buffer and chloroform in a ratio of 2:10:1, and the homogenate clarified by centrifuging at $7,000 \mathrm{~g}$. The supernatant was mixed with an equal volume of dilutions of the antiserum by the microprecipitin technique (6).

\section{HOST RANGE}

Both DGBV and DLV were mechanically transmitted singly or together from infected Dioscorea, using leaves triturated in phosphate buffer with antioxidant, to healthy $D$. composita seedlings. However, the DLV alone did not incite symptoms in Dioscorea or in any of the following species: Ageratum houstonianum, Amaranthus caudatus, Antirrhinum majus, Beta vulgaris, Brassica rapa, Callistephus chinensis, Chenopodium amaranticolor, C. foeditum, C. quinoa, Cucurbita maxima, C. pepo, Cynara scolymus, Dianthus barbatus, Helianthus annuus, Lobelia erinus, Luffa acutangula, Momordica balsamina, Nepeta cataria, Nicotiana clevelandii, $N$. rustica, $N$. tabacum, Petunia hybrida, Phaseolux vulgaris, Pisum sativum, Salpiglossis sinuata, Glycine max, Torenia fournieri, Vigna unguiculata, and Vinca rosea. None of the above species were assayed for latent virus infection.

\section{PHYSICAL PROPERTIES}

Physical properties were determined from purified virus in $0.025 \mathrm{M}$ phosphate buffer. The concentration of virus used in thermal-inactivationpoint and aging-in-vitro studies was $0.2 \mathrm{mg} / \mathrm{ml}$. Virus used in dilution-endpoint determinations was a 10 -fold dilution series of $0.2 \mathrm{mg} / \mathrm{ml}$ in phosphate 

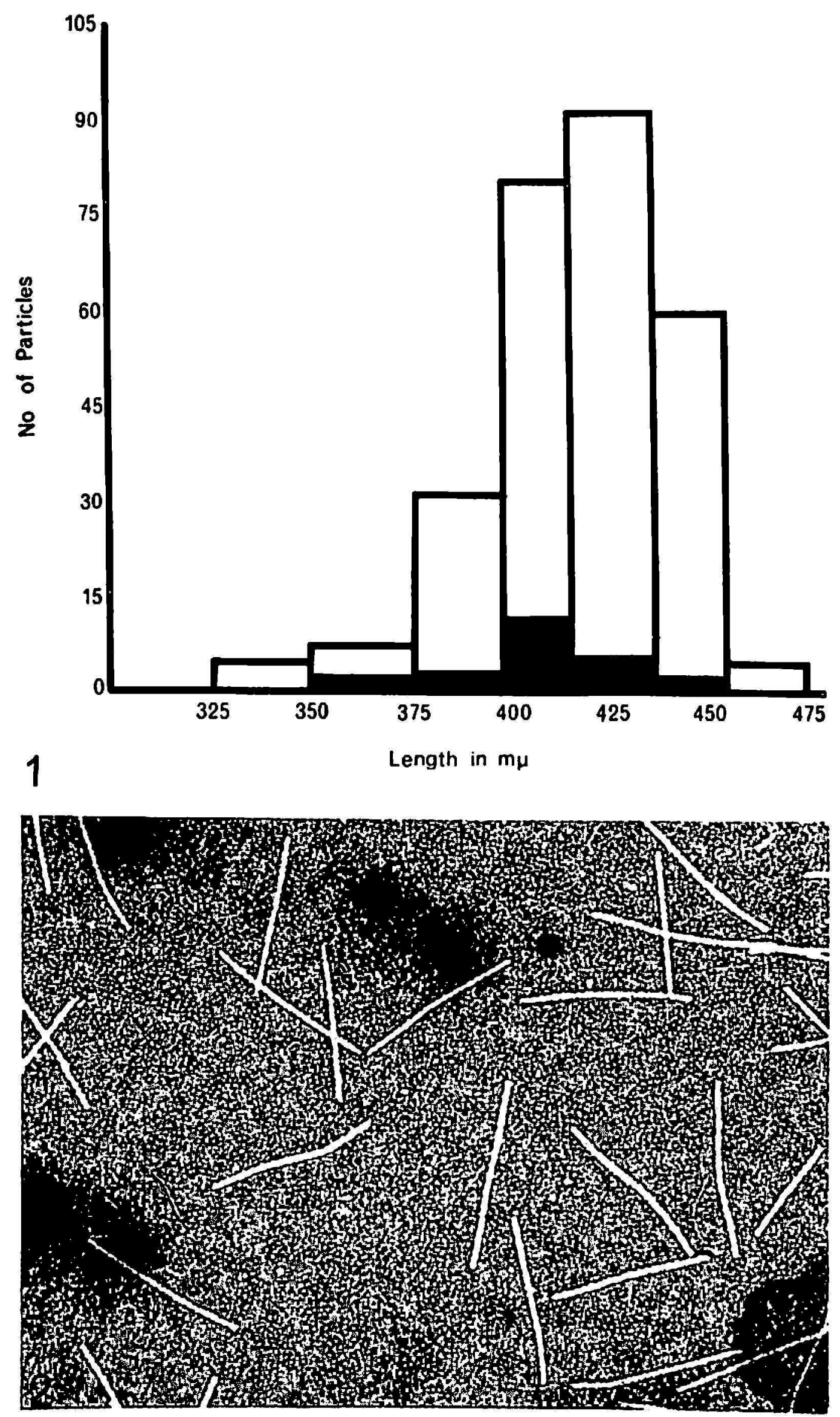

Fig. 1.- Particle length dist ribution of dioseorea latent virus in a purified density gradient fraction (open bar) and a dip preparation from symptomless plants inocillated with the gradient fraction (solid bar).

Fig. 2. Particles from the ult raviolet alsorbing zone in a sucrose density gradient column stained with neutral 2 pereent P'TA. $\times 52,000$. 
buffer. As the bioassay host Dioscorea did not show symptoms, all inoculated plants including controls were examined for virus particles with the electron microscope about 3 months after the inoculations were made using the leaf dip technique. Particles were observed in plants inoculated with virus, 1) heated to $55^{\circ} \mathrm{C}$ for $\left.10 \mathrm{~min}, 2\right)$ held in vitro $\left(\right.$ at $22^{\circ} \mathrm{C}$ ) for $24 \mathrm{~h}, 3$ ) diluted $2 \times 10^{-7}(0.002 \mu \mathrm{g} / \mathrm{ml})$, and 4) inoculated with untreated control virus. No particles were found in plants inoctiated with virus held in vitro for 30 or $40 \mathrm{~h}$, or virus previously heated to $60^{\circ} \mathrm{C}$.

\section{DISCUSSION}

It is not known how widespread DLV is in commercial plantings, nor whether it has any detrimental effects on the hosts or on yield.

It is difficult to place DLV into a well-described category of viruses. With particles ranging in length from 325 to $475 \mathrm{~nm}$, it falls between the tobacco mosaic $(300 \mathrm{~nm})$ and the potato virus $X(480$ to $580 \mathrm{~nm})$ groups of viruses. Like PVX (2), it occurs in high concentration in a natural host and is easily purified. It is strongly immunogenic, readily sap-transmissible, and is not transmitted by aphids. Unlike PVX, however, it has a small herbaceous host range, lower thermal inactivation point and aging time in vitro, and has shorter particles. We are not aware of any virus similar to DLV in many of its common characteristics.

Attempts were made with infectious purified virus to find a good locallesion host, but none was found. Suspected virus-induced tiny chlorotic lesions were observed on Cucumis sativus cotyledons and in the inoculated leaves of Nicotiana glutinosa and Gomphrena globosa. However, the subtransfer of these symptoms to healthy plants could not be attained; and attempts to detect virus serologically in these species were inconclusive.

DLV and its antiserum are available from the American Type Culture Collection as Numbers 212 and 91, respectively.

\section{SUMMARY}

A virus latent in yam species Dioscorea floribunda and D. composita (DLV) was purified by use of powdered activated charcoal and magnesiumtreated bentonite to clarify extracted Dioscorea leaf sap. The virus produced a single band in sucrose-density gradients. Antisera produced in a rabbit reached a titer of $1: 16,000$. Purified DLV did not react with antisera to any of 2is rod-shaped viruses. Myzus persicae (Sulzer), the green peach aphid, did not transmit DLV from infected Dioscorea plants. Seventy-four percent of the particles measured $395-445 \mathrm{~nm}$. Inoculated $D$. floribunda secdlings showed no symptoms, but the virus was observed in dip preparations from systemically infected growth. DLV occurred in combination 
with a second virus that was aphid-transmissible and which incited greenbanding symptoms.

\section{RESUMEN}

Un virus latente de Dioscorca floribunda y $D$. composila (DLV) se purificó mediante el uso de carbón activado pulverizado y bentonita tratada con magnesio para clarificar la savia extraida de las hojas de Dioscorea. El virus produjo una sola franja en los gradientes de densidad de la sacarosa. Los antisueros producidos en un conejo alcanzaron una concentración de $1: 16,000$. El DLV purificado no reaccionó con los antisueros a ninguno de los 25 virus cilíndricos. Myzus persicae (Sulzer), el áfido verde del melocotón, no transmitió el DLV de plantas de Dioscorca infectadas. El 74 por ciento ce lss partículas midieron de $395 \mathrm{a} 445 \mathrm{~nm}$. Las plantitas de $D$. floribunda inoculadas no revelaron síntcmas, pero el virus se observó en preparaciones por inmersión del tejido sistémicamente infectado. El DLV apareció en combinación con otro virus que era transmisible por los áfidos y que provocaba síntomas del listado verde.

\section{LITERATURE CITED}

1. Anonymous, Yam mosaic disease, leport of the Plant Pathology livision for 1964-65, Dept. Agr. Res., Nigeria, p. 36-40, 1968.

2. Bercks, R., Potato Virus X., C.M.I./A.A.B. Descriptions of Plant Viruses No. 4, 1970.

3. Dunn, D. B., and Hitchborn, J. H., The use of bentonite in the purification of plant viruses, Virology 25: 171-192, 1965.

4. Lawson, R. H., Hearon, S., Sinith, F. F., and Kahn, R. P., Electron micr.scopy and separation of viruses in Dioscorea floribunda, Phytopathology $63(1:): 1435$, 1974.

5. Ruppel, E. (.., Delpin, H., and Martin, F. W., Preliminary studies of a virus disease of sapogenin-producing Dioscorea species in Puerto Rico, J. Agr. Univ. P. R. 50: 151-7, 1966.

6. Slogteren, 1). H. M. Van. VIII, Serological microreactions with plant viruses under paraffin oil. and Conf, Potato Virus Diseases, Lisse-Wageningen Proc. 1954 $51-4,1955$.

7. Waterworth, H. E., and Kaper, J. M., Purification and Properties of Carnation Mottle Virus and its ribonucleic acid, Phytopathology 62: (9) 959-64, 1972. 